\title{
Household and Corporate Customers of Participation Banks in Turkey: Customers' Satisfaction and Bank Patronage Factors
}

Elif Guneren GENC' - H. Saduman OKUMUS² - Oksan Kibritci ARTAR ${ }^{3}$

Makale Gönderim Tarihi: 02.07.2016

Makale Kabul Tarihi: 05.09.2016

\section{Abstract}

Islamic banks (IBs) or Participation banks (PBs) in Turkey have not yet become one of the primary aspects of the Turkish financial system. The aim of this study is to empirically analyse in order for customers' awareness towards the products/services provided by $\mathrm{PBs}$, the reasons for choosing to bank with PBs, and customers' satisfaction from the participating banking products and services in Turkey. To our knowledge this study has been carried out based on the most detailed and comprehensive data ever used in terms of comparative analysis of conventional banks and the PBs.

Keywords: Islamic Banking, Participation Banking, Customer Satisfaction, Customer Awareness, and Bank Patronage, Turkey

This research was supported by Istanbul Commerce University - YAPKO. Corresponding autor: Asst. Prof. Dr., Faculty of Business Administration, Istanbul Commerce University, e-mail:elifg@ticaret.edu.tr

2 Prof.Dr., Faculty of Business Administration, Istanbul Commerce University, e-mail:sokumus@ticaret.edu.tr

3 Asst. Prof. Dr., Faculty of Business Administration, Istanbul Commerce University, e-mail:okibritci@ticaret.edu.tr 


\section{öz}

İslami bankacılık veya katılım bankacılı̆̆ı Türk finansal sisteminin henüz önemli bir bileșeni olamamıștır. Bu çalıșmanın ama$\mathrm{Cl}$, Türk Katılım Bankaları tarafından sunulan bankacılık ürünlerine yönelik, müșteri farkındalığı, banka seçim kriterleri ve müșteri tatmin seviyesini verilere dayanarak istatiksel olarak analiz etmektir. Çalıșmada, Türkiye'nin çeșitli illerinden 727 hanehalkı ve 109 ișletme katılımcılarından olușan bir örneklem kullanılarak 3 Temmuz - 23 Eylül 2015 dönemi arasında anket yoluyla veri toplanmıștır. Çalıșma, Türk katılım bankacılığı sektörüne yönelik bilgimiz dahilinde bugüne kadar yapılan en detaylı ve kapsamlı güncel verilere dayalı analizi içermektedir.

Anahtar Kelimeler: İslami Bankacılık, Katılım Bankacılığı, Müșteri Memnuniyeti, Müșteri Farkındalığı, and Türkiye

\section{INTRODUCTION}

Islamic finance/banking has grown rapidly all over the world since its inception in the early 1980s in the following of the establishment of the Islamic Development Bank. While the developing economies provide significant opportunities for a rapid growth of interest-free financial market, it is observed that various financial products and services without interest have launched in many developed countries as well. As a result of these efforts, Islamic finance and banking sector has grown at a rate of $19 \%$ annually over the period of 2009-2015 although the negative outcomes of the Global Finance Crisis spreading in the financial markets.

The survey done by The Banker (2015) indicated that Islamic financial institutions have adapted their business models to new sets of market conditions. It reported 360 financial institutions engaging in Shariah compliant activities in total while only 111 of which were the ones operating in the form of "Islamic windows", the rest was wholly Shariah compliant independent financial institutions. Furthermore, the survey also indicated that almost $79 \%$ of those institutions reported an increase in their total assets while $21 \%$ reported a decrease in the total assets. Also, 294 of the institutions studied in this report registered increasing profits while 
only 52 of those reported a fall in their profits over the period of 2014-2015. This is evident of that Islamic financial institutions all over the world have been performing well in recent years despite socio-political inconveniences in the Middle East and its periphery.

As a predominantly Muslim country, the positive attitude towards Islamic methods of finance arising from religious beliefs is already strong in Turkey. Despite Turkey's Muslim identity with a Muslim population of almost 99 percent, the attitude of the Turkish government towards the participation banking historically, can be defined as "hesitant" or "timid". The hesitant or rather inconsistent political will towards participation banking could be justified by the laicist attitude by the Turkish establishment that undermined an efficient orientation of economic and financial choices with regard to the development of participation banking in the preAKP period (Asutay, 2013). Yet, having said that, the rise of the Islamic friendly AKP (Justice and Development Party) government following the 2003 election was expected to trigger expansion of participation banking in Turkey. This would have been achieved with the help of new religio-capitalists (Islamic businessmen) as well as conservative households accumulating their wealth by use of participation banking products and this expectation is partly marched as evident by the $35 \%$ growth rate of the total assets of PBs in the last decade.

This study aims to empirically examine the awareness of household and corporate customers towards participation banking principles and products, customers' bank patronage factors as well as the satisfaction of those from the products and services provided by the Participation Banks (PBs) in Turkey. Having in mind that the duality of conservatism and modernism have a potential to influence individual consumption habits for financial services and products such as; credits, deposits and insurance, it is hoped that this study would be indirectly providing some insights regarding the interaction between religiosity and customer attitudes towards the participation banking in Turkey which is a growing area of inquiry these days. 
The remaining part of this study is divided into five subsections. The first sub-section glanced at the Islamic/Participation banking industry by highligting the crucial points that influenced the shape of the industry in recent years. A comprehensive literature review mainly on customers' satisfaction, bank patronage factors, and awareness towards Islamic principles, and also Islamic banking (IBs) products/services, is placed in the second sub-section. The third sub-section explains the data and methodology used in the study, leading to the empirical results in the following section. The final section focuses on conclusions and implications that are derived from the study.

\section{A Brief Overview of Islamic/Participation Banking (2005-2015)}

The principles of Islamic banking or participation banking include the prohibition of Riba (usury or interest) and the removal of debt-based financing, the prohibition of Gharar, encompassing full information disclosure, the removal of asymmetric information in contracts, the avoidance of risk-taking and the exclusion of financing and dealing in "sinful" activities and commodities.

The Islamic finance/banking industry worldwide has experienced years of a-double-digit growth of almost $16 \%$ in assets from 2007 to 2013 , followed by a single digit growths of approximately $9 \%$ in 2014 and $8 \%$ in 2015. The recent survey on the $\mathrm{IBs} / \mathrm{PBs}$ also indicated that almost $79 \%$ of those institutions reported an increase in their total assets while only $21 \%$ reported a decrease in their total assets. Also, 294 of the institutions studied in the report registered a profit increase while only 52 institutions reported a fall in their profits for the years of 2014 and 2015. This is evident of that Islamic financial institutions globally have been performing well in recent years though it has experienced a slight drop in the growth of total assets in 2014 and 2015 (The Banker, 2015).

The Banker (2015) report attributed this fall to consolidation in some markets, new regulatory changes, market saturation in highly banked economies and the exchange rate differentials of 
several local currencies. For example, due to the fact that Iranian Rials (IRR) considerably depreciated against the US dollar, the total assets of IBs/PBs in the worldwide scale had to confront a fall of almost $40 \%$. Despite the drop in total assets, the Report indicates that the market is still heading in the right direction with Islamic financial institutions improving access to and delivery of services, especially developing microfinance services and forming stronger strategic partnerships across Asia.

The core market and the bulk of Islamic banking/Participation banking industry are concentrated in nine core markets. These markets can be counted as; Bahrain, Qatar, Indonesia, Saudi Arabia, Malaysia, United Arab Emirates, Turkey, Kuwait and Pakistan. Together they account for $93 \%$ of the whole industry assets, which is to be estimated to exceed the level of USD 920 billion in 2016 (World Islamic Banking Competitive Report, 2016). According to this report, the total assets of Islamic banking with commercial banks in Qatar, Indonesia, Saudi Arabia, Malaysia, Uman and Turkey (QISMUT) are set to exceed USD 801 billion in 2015, representing $80 \%$ of the international Islamic banking assets. It is worth stressing that despite political and economic volatility in these regions, Islamic banking industry continues to show a strong growth of $16 \%$ in recent years. Based on the figures presented in this report, the participation banking industry in Turkey is ranked 6th in terms of the market share based on total assets in QISMUT region. The leading market share belongs to Saudi Arabia (33\%), followed by Malaysia (15.5\%), UAE (15.4\%), Kuwait (10.1\%) and Qatar (8.1\%). One of the similar survey done by Ernst and Young (2014) confirmed the outcomes of the survey mentioned above, also concluding that a-19\% annual growth rate in total assets will be achieved through the years of 2014-2019, reaching to a total assets of USD 1.8 trillion. The Ernst \& Young (2014) reveals the regional dynamics for the given six core countries of QISMUT in details. Accordingly, the market share of the GCC countries accounts to $33 \%$ whereas ASEAN countries only have $14 \%$ market share in total assets. South-Asian origin countries with a market share of $12 \%$ ranked as the third region among QISMUT countries. 
Participation Banks or Islamic Banks providing interest free banking products/services in Turkey were launched its operations initially in 1983. Albaraka Turkish Special Finance House, the first financial institution providing interest free financial products was established in 1985. In 2005 Special Finance Houses (SFHs) were renamed as Participation Banks operating under the Banking Law no: 5411 . As of 2015, there are five PBs operating in Turkey with a total asset of TL120.253 million, including newly established a state-owned Ziraat Participation Bank in that year. As was expected, another state-owned participation bank, Vakıf Participation Bank, opened its branch in 2016. In the Turkish dual banking system, the PBs operate side by side with their depository and non-depository conventional counterparts, the number of which reached to 45 in 2015.

Although Turkey has a developing economy, it has macroeconomic problems and fragile financial markets and faced several economic crises in 1994, 2000, 2001 and 2008 over which the PBs survived. However, the market share of PBs in the Turkish banking sector has only reached to the highest level of $6 \%$ since their inception in the early-1980s. It is not wrong to pronounce that participation banking in Turkey has not reached to the level of those in other Muslim countries such as Malaysia and the GCC region. In comparison with Malaysian Islamic Banking, for example, that was also launched as early as 1980s, the market share of the participation banking attained in Turkey would not be considered as sufficient yet due to endogenic and exogenic factors influencing the development process in a negative way. The collapse of some interest free financial institutions (for example İhlas Finance Institution and Bank Asya Participation Bank) in the late 1990s and in 2014 respectively, gave negative impact to the culture of participation banking in Turkey. As such, the negative perception among the Turkish people combined with adverse effects of the collapse of Ihlas Finance Institution and Bank Asya Participation Bank made a detrimental effect on the demand of the participation banking products/services which hamperred the expansion of the sector domestically. 


\section{Literature Review}

Over the last decade, we have been observing an increase in the number of studies addressing the issues such as; customers' bank selection criteria, the level of awareness and the use of participation banking products and services. The most of the studies on customer satisfaction and bank selection criteria for IBs reveal rather an interesting wide range of observations.

One of the earlier studies deserved to be mentioned here is carried out by Haron, Ahmad and Planisek (1994) study concluded that there were many similarities between Muslims and nonMuslim customers in their bank selection factors and utilization of products and services. The research was carried out in a plural society of Malaysia.

To examine the relationship between service quality perception and customers' satisfaction in the Islamic banking sector, many scholars recoursed to the use of a-six dimension SERVQUAL measurement in recent years. One of those studies considered the Malaysian Islamic banking industry was done by Amin (2008). By interviewing the bank deposit customers (muslim and non-Muslim) at bank branches, he collected the necessary data, applied the six dimensions of SERVQUAL to achieve the aim of the study. It was found that the majority of the Islamic banking customers were satisfied with the overall service quality provided by their banks. The findings suggest that the standard model of Islamic banking service quality dimensions should consist of the six dimensions and good determinants of satisfaction. According to the empirical results of Amin (2008) study, the relationship between service quality and customer satisfaction is significant.

One of the first studies conducted in Bahrain is the study of Al-Ajmi et al. (2009). The purpose of this paper is to report the motives that disposed of customers to choose a specific bank, the level of familiarity of customers with the most widely used services/products offered by $\mathrm{IBs}$, and the extent of use of those products. The necessary data was collected from 655 respondents who either bank in a Commercial Bank (CB) or IB or both. Based on statistical results, it is found that "religiosity" and "social res- 
ponsibility" are the two most important factors that determine bank selection. "Cost benefit" is the third most important factor considered in bank selection; customers of CBs and IBs share a number of motives, but they differ significantly on a few motives in relation to bank selection; and clients of Islamic banks are more familiar with the products/services that conform to the Shariah. Overall, for customers who bank exclusively with IBs, and for those who bank in different kinds of banks, the most widely used product/service of IBs is Murabaha.

The paper investigating the attitudes of Libyan business firms towards Islamic methods of finance was carried out in the study of Gait et al. (2009). A sample of 296 firms is surveyed using phone interviews during December 2007 and January 2008 to collect the data for their awareness and perceptions of Islamic finance. The results indicate that most firms have knowledge about the existence of IBs, while more than two-thirds of respondents know the specific products of Musharakah (full-equity partnerships) and Quard Hassan (interest-free benevolent loans), often through personal informal lending. However, many respondents are uninformed regarding most other Islamic financing methods. Factor analysis is used to reduce the large number of explanatory variables used to determine business firm attitudes to just four determinants: namely, "religion", "profitability", "business support", and "unique services". As the other relevant studies investigated IBs in different contries, discriminant analysis confirmed that religion remains the primary motivation for the potential use of Islamic finance among business firms in Libya.

Lee and Ullah' in (2011) provided a significant contribution to IBs' selection criteria where the importance of Shariah compliance and bank patronage factors for CBshas been explored. Aiming to investigate the determinants of customers'bank selection for IBs in Pakistan and thereby the potential risk of deposits withdrawal in case of violations of Shariah principles, they presented the descriptive statistics and cross-tabulation analysis based on data collected from 357 customers living in Peshawar city, Pakistan. They found that IBs' customers highly value Shari'a compliance in theirbanks 
and that non-compliance with Shariah principles leads to disgruntled customers. One of the most interesting pronouncements of the study is that if an IB is involved in repeated violations of Shariah, the customers are inclined to switch their banks.

Saad (2012) aimed to explore the relationship between different demographic factors and satisfaction of banks' customers in Malaysia. The results of the study suggest that the customers are mostly satisfied with "quality of services" which include "competency", "friendliness", and "staff efficiency".

Amin, Isa and Fontaine (2013) study attempted to measure customer satisfaction and its effect on image, trust and loyalty for IBs. Based on the review of the relevant literature they found out that customer satisfaction had a significant relationship with image, image had a significant relationship with trust, and trust had a significant relationship with customer loyalty for both customer segments. The findings suggest that Muslim customers established relationship with IBs since they trusted that IBs provided Shariah complaint financial products and services.

Abdullah Sidek and Adnan (2012) study presents a different approach in comparison with most of studies of participation banking in the sense that this study only deals with non-Muslim customers' perception of Islamic banking products and services in Malaysia. Based on the findings of the analysis built on the data involved 152 respondents, the study showed that Islamic banking services made headway among non-Muslims in Kuala Lumpur. In relation to the degree of perception, the link between religion and education could not be established with the perception that the establishment of Islamic banking will improve the overall banking.

It is obvious from the findings of some studies that religion is not a sole motivation for the $\mid \mathrm{Bs}^{\prime}$ customers to deal with those banks. Kader et al., (2014) study reported that Malaysian customers preferred banking with an Islamic bank (namely Bank Rakyat) because of its quality service, its return and its physical image. The oucomes of this study suggests that IBs should increase their customer satisfaction as well as providing more attractive cost benefit products as their marketing strategy. In addition to that 
there is no difference between Muslim and non-Muslim customers in terms of the bank patronage factors.

Dhurup, Surujlal and Redda (2014) studied the rapid advancement in technology-based systems, especially those related to the Internet, has led to fundamental changes in how banks interact with customers. Their study provides insights on a framework for understanding customer perceptions of the quality of technologybased banking service and the relationship with customer satisfaction and loyalty in a developing country. The findings provide evidence that the seven dimensions of technology based service quality positively influence customer satisfaction and loyalty. The results show that periodic measurements of the levels of online banking service quality should become an integral part of any bank's effort and strategy in improving service quality levels.

Sayani's (2015) study aimed to identify the determinants of customer loyalty in IBs and CBs. More than 300 respondents in United Arab Emirates were surveyed to highlight the factors that lead to continuing a relationship with IBs and CBs. The results of the study indicates that IBs' customers are satisfied with the Sharia Advisory Board, number of branches, handling issues on the phone but there is a negative correlation between advice by the personnel and lenght of association as a proxy of customer loyalty.

The impact of religiosity on consumer attitudes towards Islamic banking in Egypt was explored in the study of Youssef, Kortam, Abou-Aish and Bassiouny (2015). The findings of this survey are of practical importance for marketing of Islamic banking products as they reflect on the likely role of religiosity that would play in shaping the attitudes of potential customers toward those products. Abdi's (2015) study differs from the other studies in the sense that its sample is constituted of the international students studying at the selected Malaysian Universities rather than banks' customers. The motivation for the sampling is justified with the extensive numbers of Muslim international students in Malaysia, having contributed not only the country's education sector, but also the Islamic banking industry as well. Thus, the aim of the study is determined to examine the factors that influence Muslim international student's 
bank selection criteria of Islamic banking. A total of 163 usable responses through a survey questionnaire were analysed. The outcome of the study indicates that 43 percent of the variance of Muslim international student's selection criteria to choose Islamic banking system can be explained by the variables which are "religiosity", "knowledge", "service", and "reputation". In addition, out of the four independent variables, the variables of "knowledge", "service" and "reputation" were found to be significant to the selection criteria of Islamic banking. On the other hand, the religiosity variable was not significant to selection criteria of Islamic banking for international university students.

One of the recent studies, Kashif, Rehman and Pileliene (2016), investigated the service quality to loyalty path in Islamic banking sector in Pakistan. The study points out that Pakistani Islamic banking customers are satisfied with service quality offered by the IBs. However, major focus of customer is on the dimensions such as; "responsiveness" and "sincerity" which are understandable in high-risk avoiding and moderately power-oriented Pakistani society.

Most of the studies investigating Turkish participation banking has been only dealt with one dimension of the subject with a very limited sample size and scope so far: for example; the studies only investigating awareness towards Islamic principles or only those of customer satisfaction or participation banking patronage factors in one city. Until the late 2000s, even the number of such studies explaining the bank patronage factors and customers' satisfaction for Turkish participation banking products was far in between. It can be noted that the relevance of the socio-political atmosphere for participation banking starting in 2007 has been provided the desired socio-political atmosphere. As a result, the number of the studies considering various aspects of the participation banking industry have increased considerably since then.

Okumus's (2005), one of the pionering empirical study exploring participation banking sector in the mid-2000s, studied the customer satisfaction and bank selection criteria regarding participation banking in Turkey. To answer the research questions, 
Okumuș (2005) study administred a survey questionnaire method to selected 161 respondents from PBs (formerly SFHs) customers visiting the sampling branches in Istanbul over the period of May 2004 through June 2004. The analysis revealed a certain degree of satisfaction with participation banking prodcuts. Despite being aware of a number of specific products and Islamic banking principles, the respondents indicated that they did not deal with them.

A similar study was also conducted in the late-2000s by Okumus and Genc (2013), collecting primary data as a means of structured survey questionnaire from $281 \mathrm{PBs}^{\prime}$ customers by using stratified random sampling from January 2009 - March 2009. This survey is also limited to the Istanbul branches of the five PBs operating in that year. There is a strong evidence in the relevant literature that "religious" was one of the criteria of the PBs customers' selection. In addition, the empirical findings of both studies revealed that there was a low level of customer satisfaction on "the limited number of branches", "the availability of a wide range of credits with favourable terms" and "high service commission and fees". The respondents also expressed their dissatisfaction with some of the PBs'facilities and despite being aware of a number of specific products and services such as Mudarabah and Mushara$k a$, they indicated that they did not deal with them. However, both studies pointed out that the relationship between customers and bank staff was the main driver of the PBs' customers' satisfaction and bank selection process in Turkey. Both studies also reveal that the reason for dealing with a $\mathrm{PB}$ not a $\mathrm{CB}$ is religiosity rather than profitability that a rational investor is supposed to seek for in his investments.

Bilir and Özgen (2010) mainly aimed to measure the level of customer satisfaction in PBs located in the province of Hatay, Turkey. SERVQUAL method desribing the level of service quality as a fraction of customer expectations and service perception of the firm regarding the service offered to customers was applied. Depending on data collected from 322 respondents, they concluded that the PBs should devote themselves to train their staff although customers had a confidience in a PB itself but not in staff in terms 
of advising about the products and services offered by the PBs. In addition to that the PBs are far away with meeting financial needs of their customers such as credits in favourable terms.

Ozsoy, Görmez and Mekik (2013) aimed to explore the reasons for preference criteria of the Turkish PBs. A sample of 217 participants from the PBs customers attended the survey in the provience of Bolu city, Turkey. By applying an exploratory factor analysis, the study revealed that the principal factor affecting the participants' bank selection decision was "product/service quality" as well as "image and trust", "personnel quality", "religious/ environmental motivations".

The number of studies claiming that there is no huge difference between the products provided by PBs and CBs in Turkey is not few. One of such studies of Kaytancl, Ergec and Toprak (2013) analysed the level of awareness and satisfaction among PBs customers since they observed that customer satisfaction was one of the most important element in the banking sector. The study used the data compiled through the survey held in Eskissehir city, Turkey, with the participation of 500 customers. Based on findings it reveals that most of the customers were satisfied with the products and services offered by the PBs and that they have high level of awareness on the PBs' products.

Savasan, Sarac and Gürdal (2013) investigated the businessperson perception from Islamic finance by utilising an extensive questionnaire sent to 1045 businessmen who are the members of a conservative business association of MÜSIAD in Turkey. The findings of the survey indicated that $60 \%$ of the respondents attended the survey prefered banking with $\mathrm{CBs}$ whereas the rest banked in PBs only.

Asutay and Ergec (2013) explored the relationship between money, deposits, and loans (financing) in the context of Malaysian and Turkish Islamic and conventional bankings. Based on data collected from January 2007 to May 2013, the study applied Granger causality test as a method of analysis. The results showed that the direction of the causality between loans and deposits was the same in both Malaysia and Turkey. Therefore, it appears that 
the direction of the causal relations is the same in the Turkish CBs and PBs.

One of the recent studies aiming to evaluate the customer satisfaction and loyalty for private and state-owned CBs as well as PBs in Turkey is the study of Șendoğdu (2014). The survey was carried out in Konya city known as one the most conservative city in Turkey by collecting data from $321 \mathrm{CBs}$ and PBs' customers. According to the findings of this study, there is no difference between customer satisfaction and customer loyalty observed, however, established a strong positive relationship between the given variables.

Ergec, Kaytancı and Toprak (2014) studied bank selection preferences of $\mathrm{PBs}^{\prime}$ customers to better understand their attitude towards "Islamic windows", which is not operational in Turkey yet. The data collected from 500 bank customers in Eskișehir city, Turkey. Based on the data and findings, the customers of PBs have positive attitude towards "Islamic banking windows" if the CBs provide participation banking products and services in Turkey.

The participation banking sector in Turkey has attracted many non-Turkish scholars, inspiring them to investigate the sector academically. Boulam's (2015) focused on the participation banking in Turkey. Having strongly indicated that Turkey bridges the East and the West as a secular country, Boulam (2015) study attempted to eleborate if Turkey could be a global financial hub in the region. By analysing the subareas of the Global Financial Centers Index which considers the current growth rate of the participation banking industry and the support by the state in the foundation of a state-owned PB, the study attampted to determine the possible contribution of Islamic finance/banking tools to the Turkey's way in becoming a global financial hub. The methodology used in the study is the Z/Yen Index providing ratings for financial centres calculated by a 'factor assessment model'. Based on the findings of Z/yen index analysis the study concluded that Turkey had a great potential and strengths to become an international financial hub.

Finally, Artar, Okumus and Genc, (2016) study also compared the $\mathrm{PBs}$ customers with the $\mathrm{CBs}^{\prime}$ ones in terms of bank selection 
criteria, awareness towards Islamic principles and use of banking products. A sample of 1082 respondents from various cities in Turkey is used in the study. It appears that the customers of PBs and $\mathrm{CBs}$ seem not to be significantly different in terms of preference of banking products. While most of the PBs' customers mostly use either current accounts or credit cards, most of the CBs' customers mostly use consumer credits offered by the CBs as well as current accounts and credit cards. Based on the empirical results, it is also clear that there is a high level of awareness in public towards Islamic principles that are supposedly adopted by the PBs in their banking operations. It is worth noting that in a comparative manner businessmen in Turkey act rational regardless of whether it is a $C B$ or a $P B$ as long as banking products and services offered by the given banks meet their business needs.

\section{Methodology and Data}

The data collected though questionnaire and the survey was though out Turkey by taking into consideration the 3-level Statistical Regions (SR) by the Turkish Statistical Institute. To be able to run the survey Turkey-wide at SR Level 1 and 2, quota sampling was used because of considerable difficulties in actually locating and interviewing each member of the population. Nonetheless, once the quotas of the PB branches with transaction volumes determined, the interviews carried out randomly. Eventually, a-large sample of 727 household and 109 corporate customers of PBs constituted the database that statistical analysis was built on. To our knowledge, this study has been carried out based on the most detailed and comprehensive data ever used regarding the PBs in Turkey. Descriptive statistics and chi-square are reported. (Descriptive statistics in Table I, Table II, Table III, Table IV and Table V; chi-square test in Table VI and Table VII)

The questionnaire is designed in six sections: Section one includes demographic information about the households and corporate customers of the PBs such as gender, age, level of education, types of employees and jobs, years on job, monthly income, age of company, legal entity of company, number of employees, 
and financial turnover of company. In the second section, the main reasons behind customers not solely dealing with a PB are assessed with a number of nine items. Section three comprises of the information on financial products and services utilised by the PBs' customers. In Section four, twelve items are selected to determine PBs' households and corporate customer awareness and their use of participation banking products. Section five engages in the reasons behind dealing with a PB. Sixteen selection criteria are used in order to detect the selection criteria of the PBs customers. Section six evaluates the PBs on twelve items in order to determine the main drivers of the PBs' customer satisfaction towards the financial products and services.

All items, except for those in Section four, were measured on five-point likert scales from 1 (Not aware of/Very un-satisfied) to 5 (Strongly agree/Very satisfied). In Section four, respondents were invited to express the level of awareness and use of different products/services on the basis of "Not aware of it", "Low awareness of it", Aware and do not use it", "Aware and use it" and "Well aware of it".

The present study follows the patterns of Okumus (2005) and Okumus and Guneren Genc (2013). Both the studies are concluded in Turkey, however they are limited in scope due to the selection of sample. The given studies limited their study to the customers of PBs operating in Istanbul city only, however this study is not limited in scope as the data is collected at large without restricting it to one city or to a few branches of PBs, expanding the survey to the Turkey-wide level.

\section{Empirical Findings}

In this section, to be able to distinguish the preferences of the PBs' household and corporate customers, the empirical findings will be presented separately in the following tables.

\section{Household and Corporate Respondents' Descriptives}

With regard to the responses of individual customers participated in the survey, as it reveals from Table I below, $84.5 \%$ are 
male and $15.5 \%$ are female respondents. More than $50 \%$ of the respondents regarded themselves that they absolutely fulfil the requirements of Islam religion. The largest age group of respondents is from the age group of 25 to 44 years old, which accounted for $27.5 \%$. Besides it seems that most of the respondents graduated from high school, which consists of $38.9 \%$, and followed by respondents holding a bachelor degree which comprising of $26.8 \%$. A-third of the respondents $(33.4 \%$ ) responded that they work at a privately owned firm, mostly engaging in service sectors. Those dealing with trade followed this. As is denoted in Table I more than $50 \%$ of the household respondents had a working experience for 9 years in the sector they are engaged in. Approximately $30 \%$ of the respondents had an income of between TL2000-6000.

\section{Table I: Background of Household and Corporate Respondents}

\begin{tabular}{|c|c|c|c|c|c|c|c|c|c|c|c|}
\hline$n=727$ & & & Household & & & $n=109$ & & & Corporate & & \\
\hline Age & Frq. & $\%$ & Years in Business /Job & Frq. & $\%$ & Age of Company & Frq. & $\%$ & "Financial Turnover of Comp. & Frq. & $\%$ \\
\hline 15-24 years old & 42 & 5.8 & Unemployed & 10 & 1.4 & under 5 year & 22 & 20.2 & $0-199.000 \$$ & 37 & 33.9 \\
\hline $25-34$ years old & 119 & 16.4 & Less than 5 years & 173 & 23.8 & $5-9$ year & 19 & 17.4 & $200.000 \$-299.000 \$$ & 6 & 5.5 \\
\hline $35-44$ years old & 81 & 11.1 & $5-9$ years & 156 & 21.5 & $10-14$ year & 24 & 22.0 & $300.000 \$-499.000 \$$ & 4 & 3.7 \\
\hline 45-54 years old & 34 & 4.7 & $10-14$ years & 101 & 13.9 & $15-19$ year & 11 & 10.1 & $500.000 \$-749.000 \$$ & 3 & 2.8 \\
\hline $55-64$ years old & 15 & 2.1 & $15-20$ years & 86 & 11.8 & more than 20 year & 33 & 30.3 & $750.000 \$-999.000 \$$ & 2 & 1.8 \\
\hline more than 65 years old & 4 & 0.5 & More than 20 years & 118 & 16.2 & Type of Company & & & $1.000 .000 \$-1.499 .000 \$$ & 11 & 10.1 \\
\hline Missing Value & 432 & 59.4 & Missing Value & 83 & 11.4 & One Partner & 43 & 39.4 & $1.500 .000 \$-1.999 .000 \$$ & 4 & 3.7 \\
\hline Gender & & & Type of Business Sector & & & Family Company & 49 & 45.0 & $2.000 .000 \$-2.999 .000 \$$ & 4 & 3.7 \\
\hline Male & 614 & 84.5 & Manufacture & 54 & 7.4 & Non-Family Partnership & 7 & 6.4 & $3.000 .000 \$-4.999 .000 \$$ & 8 & 7.3 \\
\hline Female & 113 & 15.5 & Trade & 129 & 17.7 & Comp. of Public Ownership & 9 & 8.3 & $15.000 .000 \$-19.999 .000 \$$ & 2 & 1.8 \\
\hline Practicing Religion & & & Agriculture & 5 & 0.7 & Missing Value & 1 & 0.9 & More than $100.000 .000 \$$ & 1 & 0.9 \\
\hline Absolutely & 419 & 57.6 & Finance and Tourism & 49 & 6.7 & Number of Employees & & & Missing Value & 27 & 24.8 \\
\hline Partly & 243 & 33.4 & Construction & 59 & 8.1 & $1-5$ person & 57 & 52.3 & Title of Company & & \\
\hline None & 48 & 6.6 & Education & 50 & 6.9 & $6-11$ person & 27 & 24.8 & Limited Company & 45 & 41.3 \\
\hline Missing Value & 17 & 2.4 & Services & 187 & 25.7 & $12-17$ person & 12 & 11.0 & Stock Company & 16 & 14.7 \\
\hline Level of Education & & & Missing Value & 194 & 26.8 & $18-23$ person & 4 & 3.7 & Unlimited Company & 45 & 41.3 \\
\hline Non-Literated & 1 & 0.1 & Type of Employers & & & $24-29$ person & 1 & 0.9 & Collectiv Company & 2 & 1.8 \\
\hline Literate only & 1 & 0.1 & State employee & 20 & 2.8 & more than 30 year & 8 & 7.3 & Public & 1 & 0.9 \\
\hline Primary School & 81 & 11.1 & State officer & 55 & 7.6 & Type of Business Sector & & & & & \\
\hline Secondary School & 87 & 12.0 & Private employee & 243 & 33.4 & Manufacture & 20 & 18.3 & & & \\
\hline High School & 283 & 38.9 & Private officer & 73 & 10.0 & Wholesale & 25 & 22.9 & & & \\
\hline Community College & 51 & 7.0 & Self-employed & 64 & 8.8 & Retail & 42 & 38.5 & & & \\
\hline Bachelor's degree & 195 & 26.8 & Specialized professions & 48 & 6.6 & Services & 22 & 20.3 & & & \\
\hline Master & 26 & 3.6 & Craft & 140 & 19.3 & & & & & & \\
\hline Doctorate & 2 & 0.4 & Retired & 16 & 2.2 & & & & & & \\
\hline Monthly Net Income & & & Housewife & 17 & 2.3 & & & & & & \\
\hline $0-1999 \mathrm{TL}$ & 32 & 4.4 & Student & 41 & 5.6 & & & & & & \\
\hline $2000 \mathrm{TL}-3999 \mathrm{TL}$ & 171 & 23.5 & Missing Value & 10 & 1.4 & & & & & & \\
\hline 4000TL - 5999TL & 57 & 7.8 & & & & & & & & & \\
\hline $8000 \mathrm{TL}$ - More than & 0 & 0.0 & & & & & & & & & \\
\hline Missing Value & 467 & 64.3 & & & & & & & & & \\
\hline
\end{tabular}

As we considered the descriptives of corporate respondents, based on the figures in Table I below, $45 \%$ of the respondents pronounced that they worked for their family business. $60 \%$ the corporate respondents had been operating in the sector for more than 10 years. In addition to that, $77 \%$ of the corporate customers 
based on the data collected have less than 11 employees, indicating to a micro business scale. Almost over $30 \%$ indicated that their firms had less than USD200.000 financial turnover annually. The majority of the corporate respondents $(38.5 \%)$ got involved in the retail sector and those followed by the wholesale one.

\section{Respondents' Use of Products/Services}

Table II reports the findings in connection with the types of accounts held by the household and corporate respondents and the length of time they held their accounts and services utilised. It reveals from the figures in Table II, almost $60 \%$ of the households has current accounts with a PB more than one year. This rate is $68 \%$ for corporate respondents. However, only $35 \%$ of those have kept up their relationship with a PB for more than three years. This might imply a low level of customer loyalty towards PBs.

It appears that half of the household and corporate respondents has been holding the credit cards given by PBs for more than one year. In addition, almost $14 \%$ of the household respondents had recoursed to consumer credit facility based on Murabaha at least one year ago. However, one third of the corporate respondents had recoursed to the individual finance products of the PBs in the form of commercial credit at least one year ago which operates in compliance with the principle of Murabaha. Based on the data, it is not wrong to pronounce that both household and corporate customers tend to use rather credit-like products/services of the PBs than deposit ones. 


\section{Table II: Length of the Accounts/Services Held and Utilised}

\begin{tabular}{|c|c|c|c|c|c|c|c|c|c|c|c|c|c|}
\hline \multirow[t]{2}{*}{ n=727 (Households) } & \multicolumn{2}{|c|}{$\begin{array}{l}\text { Do not have or } \\
\text { not applicable }\end{array}$} & \multicolumn{2}{|c|}{$\begin{array}{l}\text { Used for Short } \\
\text { Period }\end{array}$} & \multicolumn{2}{|c|}{ Less than 1 year } & \multicolumn{2}{|c|}{ 1-3 year } & \multicolumn{2}{|c|}{ 3-5 year } & \multicolumn{2}{|c|}{$\begin{array}{l}\text { More than } 5 \\
\text { years }\end{array}$} & \multirow{2}{*}{$\begin{array}{c}\text { Missing } \\
\text { Frq. }\end{array}$} \\
\hline & Frq. & $\%$ & Frq. & $\%$ & Frq. & $\%$ & Frq. & $\%$ & Frq. & $\%$ & Frq. & $\%$ & \\
\hline $\begin{array}{l}\text { Current Accounts } \\
\end{array}$ & 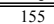 & 21.4 & $\frac{16}{46}$ & 6.3 & 97 & 1013.3 & 16165 & 222.7 & 98 & 13.5 & $=160$ & 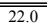 & 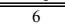 \\
\hline $\mathrm{P} / \mathrm{L}$ Participation Accounts & 465 & 64.0 & 29 & 4.0 & 55 & 7.5 & 73 & 10.0 & 34 & 4.7 & 60 & 8.3 & 11 \\
\hline Consumer Credit & 567 & 78.0 & 27 & 3.7 & 35 & 4.8 & 49 & 6.7 & 34 & 4.7 & 13 & 1.8 & 2 \\
\hline Foreign Currency & 531 & 73.0 & 18 & 2.5 & 39 & 5.4 & 53 & 7.3 & 41 & 5.6 & 42 & 5.8 & 3 \\
\hline Individual Pension & 564 & 77.6 & 23 & 3.2 & 33 & 4.5 & 53 & 7.3 & 32 & 4.4 & 16 & 2.2 & 6 \\
\hline International Foreign Trade Goods/Services & 681 & 93.7 & 6 & 0.8 & 4 & 0.6 & 23 & 3.2 & 8 & 1.1 & 4 & 0.6 & 0 \\
\hline Credit Card & 280 & 38.5 & 17 & 2.3 & 47 & 6.5 & 132 & 18.2 & 115 & 15.8 & 136 & 18.7 & \\
\hline Cheque & 637 & 87.6 & 6 & 0.8 & 19 & 2.6 & 18 & 2.5 & 14 & 1.9 & 31 & 4.3 & 2 \\
\hline Gold & 553 & 76.1 & 9 & 1.2 & 23 & 3.1 & 50 & 6.9 & 54 & 7.4 & 36 & 5.0 & 2 \\
\hline Investment Services & 590 & 81.2 & 15 & 2.1 & 24 & 3.2 & 54 & 7.4 & 29 & 4.0 & 11 & 1.5 & 4 \\
\hline Sukuk & 701 & 96.4 & 11 & 1.5 & 5 & 0.7 & 4 & 0.6 & 3 & 0.4 & 1 & 0.1 & 2 \\
\hline \multirow[t]{2}{*}{$n=109$ (Corporate) } & \multicolumn{2}{|c|}{$\begin{array}{l}\text { Do not have or } \\
\text { not applicable }\end{array}$} & \multicolumn{2}{|c|}{$\begin{array}{c}\text { Used for Short } \\
\text { Period }\end{array}$} & \multicolumn{2}{|c|}{ Less than 1 year } & \multicolumn{2}{|c|}{ 1-3 year } & \multicolumn{2}{|c|}{ 3-5 year } & \multicolumn{2}{|c|}{$\begin{array}{c}\text { More than } 5 \\
\text { years }\end{array}$} & Missing \\
\hline & Frq. & $\%$ & Frq. & $\%$ & Frq. & $\%$ & Frq. & $\%$ & Frq. & $\%$ & Frq. & $\%$ & Frq. \\
\hline Current Accounts & 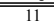 & 10.1 & 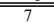 & 6.4 & 16 & 14.7 & 18 & 10.5 & 18 & 16.5 & 38 & 34.9 & 10 \\
\hline $\mathrm{P} / \mathrm{L}$ Participation Accounts & 68 & 62.4 & 5 & 4.6 & 6 & 5.5 & 11 & 10.1 & 4 & 3.7 & 11 & 10.1 & 4 \\
\hline Commercial Credit & 56 & 51.4 & 6 & 5.5 & 7 & 6.3 & 23 & 21.1 & 9 & 8.3 & 4 & 3.7 & 4 \\
\hline Foreign Currency & 66 & 60.6 & 11 & 10.1 & 2 & 1.8 & 15 & 13.8 & 3 & 2.8 & 6 & 5.5 & 6 \\
\hline Factoring & 91 & 83.5 & 4 & 3.6 & 1 & 0.9 & & & 3 & 2.8 & 1 & 0.9 & 9 \\
\hline International Foreign Trade Goods/Services & 98 & 90.0 & 2 & 1.8 & 2 & 1.8 & 1 & 0.9 & 1 & 0.9 & 1 & 0.9 & 4 \\
\hline Credit Card & 27 & 24.9 & 1 & 0.9 & 12 & 11.0 & 18 & 16.5 & 18 & 16.5 & 31 & 28.4 & 2 \\
\hline Cheque & 61 & 56.0 & 7 & 6.4 & 6 & 5.5 & 6 & 5.5 & 6 & 5.5 & 20 & 18.3 & 3 \\
\hline Gold & 84 & 77.1 & 5 & 4.6 & 2 & 1.8 & 11 & 10.1 & 3 & 2.8 & 2 & 1.8 & 2 \\
\hline POS & 30 & 27.3 & 3 & 2.8 & 15 & 13.8 & 21 & 19.3 & 10 & 9.2 & 27 & 24.8 & 3 \\
\hline Derivative Products & 86 & 78.9 & 1 & 0.9 & 1 & 0.9 & 1 & 0.9 & 4 & 3.7 & 5 & 4.6 & 11 \\
\hline Investment Services & 82 & 75.2 & 6 & 5.5 & 3 & 2.8 & 8 & 7.3 & 5 & 4.6 & 1 & 0.9 & 4 \\
\hline Sukuk & 96 & 88.1 & 1 & 0.9 & & & 2 & 1.8 & 4 & 3.7 & 2 & 1.8 & 4 \\
\hline
\end{tabular}

\section{Table III: Respondents' Awareness and Use of Products/Services}

\begin{tabular}{|c|c|c|c|c|c|c|c|c|c|c|}
\hline \multirow{2}{*}{ n=727 (Househols) } & \multicolumn{2}{|c|}{ Well aware } & \multicolumn{2}{|c|}{ Aware of } & \multicolumn{2}{|c|}{ Adequate Aware } & \multicolumn{2}{|c|}{ Low Aware } & \multicolumn{2}{|c|}{ Not aware of } \\
\hline & Frq. & $\%$ & Frq. & $\%$ & Frq. & $\%$ & Frq. & $\%$ & Frq. & $\%$ \\
\hline Interest free principles & 78 & 10.7 & 154 & 21.2 & 239 & 32.9 & 117 & 16.1 & 139 & 19.1 \\
\hline Mudarabah & 51 & 7.0 & 84 & 11.6 & 88 & 12.1 & 105 & 14.4 & 399 & 54.9 \\
\hline Musharaka & 60 & 8.3 & 102 & 14.0 & 131 & 18.0 & 109 & 15.0 & 325 & 44.7 \\
\hline Assurance Fund & & & 268 & 36.9 & & & & & 459 & 63.1 \\
\hline \multirow{2}{*}{ n=109 (Corporate) } & \multicolumn{2}{|c|}{ Well aware } & \multicolumn{2}{|c|}{ Aware of } & \multicolumn{2}{|c|}{ Adequate Aware } & \multicolumn{2}{|c|}{ Low Aware } & \multicolumn{2}{|c|}{ Not aware of } \\
\hline & Frq. & $\%$ & Frq. & $\%$ & Frq. & $\%$ & Frq. & $\%$ & Frq. & $\%$ \\
\hline Interest free principles & 10 & 9.2 & 21 & 19.3 & 39 & 35.8 & 18 & 16.5 & 21 & 19.2 \\
\hline Mudarabah & 9 & 8.3 & 7 & 6.4 & 16 & 14.7 & 17 & 15.6 & 60 & 55.0 \\
\hline Musharaka & 14 & 12.8 & 14 & 12.8 & 17 & 15.6 & 15 & 13.8 & 49 & 45.0 \\
\hline Assurance Fund & & & 53 & 48.6 & & & & & 56 & 51.4 \\
\hline
\end{tabular}

It is expected that the customers who have been dealing with PBs for some time based on the products/services understand participation banking terminology. Therefore, this study was obliged to attempt to reveal the customers' awareness towards the specific meaning of participation banking principles such as Riba, Murabaha, Mudarabah and Assurance Fund. In the questionnaires, respondents were required to express the degree of awareness of those principles and banking products offered by the PBs in Turkey. 
Based on the figures in Table III, the majority of the household and corporate respondents showed a good understanding of interest free principle of Riba with a ratio of $20 \%$. However, the findings indicate that Arabic terms such as Mudarabah 155 percent) and Musharaka (45\%) were not well understood. One fifth of the respondents cited that they were not aware of specific Islamic banking terminology such as Mudarabah, Murabaha and Musharaka. Surprisingly, only one third of the household respondents were aware of the Assurance Fund whereas the consiousness among the corporate customers towards Islamic banking terminology had been higher reaching to the level of over $50 \%$.

\section{Respondents' Bank Patronage Factors}

In the survey, the participants were invited to express the extent of their agreement with a set of reasons that may explain their banking with PBs. A statistical brief of their responses is given in Table IV below.

Based on the findings for households as seen in Table IV, it was noted that closest behavior of employees was the most important criterion for choosing to deal with a PB. It registers the highest mean score (3.92). This is followed by the factors of interest free financial institutions and provision of fast and efficient service by banks (3.84 and 3.78, respectively) Reputation and image of PBs and financial counselling provided by employees are seen to be the fourth and fifth important factors with the mean scores of 3.68 and 3.61 .

It is noted that closest behavior of employees was the most important criterion for choosing to deal with a PB for corporate respondents with the highest mean score of 3.78. This is followed by interest free financial institutions, financial counselling provided by employees (3.67 and 3.58, respectively). The factors such as location near home/place of work and fast and efficient service by banks are registered to be the fourth and fifth important factors with the mean scores of 3.45 and 3.43 . 


\section{Table IV: Respondents' Bank Patronage Factors}

\begin{tabular}{|c|c|c|c|c|c|c|c|c|c|c|c|c|c|}
\hline \multirow{2}{*}{ n=727 (Households) } & \multicolumn{2}{|c|}{ Strongly Agree } & \multicolumn{2}{|c|}{ Agree } & \multicolumn{2}{|c|}{ Disagree } & \multicolumn{2}{|c|}{$\begin{array}{c}\text { Strongly } \\
\text { Dissatisfied }\end{array}$} & \multicolumn{2}{|c|}{ No view } & \multirow{2}{*}{$\begin{array}{c}\text { Missing } \\
\text { Value } \\
\text { Frq. }\end{array}$} & \multirow{2}{*}{ Mean } & \multirow{2}{*}{$\begin{array}{c}\text { Std. } \\
\text { Deviation }\end{array}$} \\
\hline & Frq. & $\%$ & Frq. & $\%$ & Frq. & $\%$ & Frq. & $\%$ & Frq. & $\%$ & & & \\
\hline Religious reasons solely & 143 & 19.7 & 186 & 25.6 & 143 & 19.7 & 115 & 15.8 & 123 & 16.9 & 17 & 3.14 & 1.38 \\
\hline Interest-free financial institution & 262 & 36.0 & 256 & 35.2 & 53 & 7.3 & 67 & 9.2 & 69 & 9.5 & 20 & 3.84 & 1.26 \\
\hline Assurance Fund & 116 & 16.0 & 258 & 35.5 & 92 & 12.7 & 68 & 9.4 & 121 & 16.6 & 72 & 3.40 & 1.23 \\
\hline Closest behaviour of employees & 236 & 32.5 & 319 & 43.9 & 52 & 7.2 & 39 & 5.4 & 73 & 10.0 & 8 & 3.92 & 1.10 \\
\hline Recommendations by friends\&families & 98 & 13.5 & 208 & 28.6 & 150 & 20.6 & 114 & 15.7 & 128 & 17.6 & 29 & 3.04 & 1.32 \\
\hline Resistance to financial crises & 114 & 15.7 & 256 & 35.2 & 95 & 13.1 & 56 & 7.7 & 138 & 19.0 & 68 & 3.42 & 1.18 \\
\hline PB's reputation and image & 164 & 22.6 & 305 & 42.0 & 57 & 7.8 & 46 & 6.3 & 138 & 19.0 & 17 & 3.68 & 1.11 \\
\hline Fast\&efficient service & 181 & 24.9 & 319 & 43.9 & 62 & 8.5 & 31 & 4.3 & 120 & 16.5 & 14 & 3.78 & 1.06 \\
\hline Lower service charges & 154 & 21.2 & 258 & 35.5 & 83 & 11.4 & 66 & 9.1 & 111 & 15.3 & 55 & 3.52 & 1.24 \\
\hline Available credit with favourable terms & 82 & 11.3 & 227 & 31.2 & 112 & 15.4 & 88 & 12.1 & 127 & 17.5 & 91 & 3.16 & 1.26 \\
\hline FC transactions with favourable terms & 86 & 11.8 & 150 & 20.6 & 143 & 19.7 & 95 & 13.1 & 125 & 17.2 & 128 & 2.98 & 1.30 \\
\hline A wide range of services offered & 126 & 17.3 & 303 & 41.7 & 95 & 13.1 & 46 & 6.3 & 132 & 18.2 & 25 & 3.52 & 1.13 \\
\hline Availability of products\&services offered by banks & 134 & 18.4 & 329 & 45.3 & 86 & 11.8 & 40 & 5.5 & 125 & 17.2 & 13 & 3.60 & 1.09 \\
\hline Financial counselling provided by employees & 154 & 21.2 & 138 & 43.7 & 93 & 12.8 & 45 & 6.2 & 111 & 15.3 & 6 & 3.61 & 1.14 \\
\hline Location near my home/place of work & 106 & 14.6 & 275 & 37.8 & 93 & 12.8 & 45 & 6.2 & 111 & 15.3 & 6 & 3.29 & 1.21 \\
\hline Interior comfort & 145 & 19.9 & 282 & 38.8 & 82 & 11.3 & 78 & 10.7 & 130 & 17.9 & 10 & 3.47 & 1.24 \\
\hline \multirow[t]{2}{*}{ n=109 $($ Corporate $)$} & \multicolumn{2}{|c|}{ Strongly Agree } & \multicolumn{2}{|c|}{ Agree } & \multicolumn{2}{|c|}{ Disagree } & \multicolumn{2}{|c|}{$\begin{array}{c}\text { Strongly } \\
\text { Dissatisfied }\end{array}$} & \multicolumn{2}{|c|}{ No view } & $\begin{array}{c}\text { Missing } \\
\text { Value }\end{array}$ & Mean & $\begin{array}{c}\text { Std. } \\
\text { Deviation }\end{array}$ \\
\hline & Frq. & $\%$ & Frq. & $\%$ & Frq. & $\%$ & Frq. & $\%$ & Frq. & $\%$ & Frq. & & \\
\hline Religious reasons solely & 29 & 26.6 & 20 & 18.3 & 20 & 18.3 & 22 & 20.2 & 18 & 16.5 & & 3.13 & 1.50 \\
\hline Interest-free financial institution & 42 & 38.5 & 27 & 24.8 & 11 & 10.1 & 14 & 12.8 & 14 & 12.8 & 1 & 3.67 & 1.41 \\
\hline Assurance Fund & 22 & 20.2 & 28 & 25.7 & 11 & 10.1 & 14 & 12.8 & 26 & 23.9 & 8 & 3.33 & 1.31 \\
\hline Closest behaviour of employees & 40 & 36.7 & 37 & 33.9 & 6 & 5.5 & 13 & 11.9 & 13 & 11.8 & & 3.78 & 1.32 \\
\hline Resistance to financial crises & 18 & 16.5 & 34 & 31.2 & 12 & 11.0 & 19 & 17.4 & 24 & 22.0 & 2 & 3.19 & 1.34 \\
\hline PB's reputation and image & 20 & 18.3 & 38 & 34.9 & 13 & 11.9 & 18 & 16.5 & 19 & 17.4 & 1 & 3.27 & 1.35 \\
\hline Fast\&efficient service & 25 & 22.9 & 39 & 35.8 & 16 & 14.7 & 13 & 11.9 & 16 & 14.7 & & 3.43 & 1.32 \\
\hline Lower service charges & 24 & 22.0 & 37 & 33.9 & 14 & 12.8 & 16 & 14.7 & 17 & 15.6 & 1 & 3.36 & 1.43 \\
\hline Available credit with favourable terms & 19 & 17.4 & 28 & 25.7 & 12 & 11.0 & 23 & 21.1 & 20 & 18.3 & 7 & 3.08 & 1.43 \\
\hline FC transactions with favourable terms & 13 & 11.9 & 23 & 21.1 & 12 & 11.0 & 25 & 22.9 & 16 & 14.7 & 20 & 2.85 & 1.45 \\
\hline A wide range of services offered & 14 & 12.8 & 20 & 18.3 & 19 & 17.4 & 19 & 17.4 & 29 & 26.6 & 8 & 2.91 & 1.31 \\
\hline Availability of products\&services offered by banks & 21 & 19.3 & 29 & 26.6 & 15 & 13.8 & 13 & 11.9 & 30 & 27.5 & 1 & 3.28 & 1.27 \\
\hline Financial counselling provided by employees & 31 & 28.4 & 33 & 30.3 & 7 & 6.4 & 13 & 11.9 & 11 & 20.2 & 3 & 3.58 & 1.31 \\
\hline Location near my home/place of work & 34 & 31.2 & 30 & 27.5 & 11 & 10.1 & 19 & 17.4 & 15 & 13.8 & & 3.45 & 1.46 \\
\hline Interior comfort & 22 & 20.2 & 36 & 33.0 & 10 & 9.2 & 19 & 17.4 & 19 & 17.4 & 5 & 3.30 & 1.38 \\
\hline
\end{tabular}

\section{Respondents' Satisfaction from Products/Services}

Based on the data collected and the analysis applied to it, various aspects of customer satisfaction with participation banking products/services were attempted to explore in this study. The customers of the PBs in the sample were asked to express their degree of satisfaction towards various aspects of the products and services provided by the PBs. The outcomes of this part of the study are reported in Table $\mathrm{V}$ below.

The vast majority of the household respondents expressed a considerably high level of satisfaction towards various aspects of products and services. The criteria of financial counseling provided by employees showed the highest mean score of 4.12 , then followed by those of informing customer about products/services, provision of fast and efficient service confidentiality of $P B$, and $P B s$ reputation and image, respectively $(3.89,3.84$ and 3.84). As far as the performance of bank personnel was concerned, the ma- 
jority of the household respondents were satisfied with the customer-client interaction at bank branches. However, FC transactions with favourable terms and recommendations by friends/families did not get better response from the household customers with the mean scores of 3.35 and 3.11 , respectively.

In the lower part of Table $\mathrm{V}$, the statistics for corporates are denoted. The criterion of financial counseling provided by employees appeared to be the most satisfied one with PBs' products. It recorded the highest mean score of 3.97 , then, followed by confidentiality of PB and provision of fast and efficient service (3.74 and 3.73 , respectively).

\section{Table V: Degree of Household/Corporate Respondents' Satisfaction}

\begin{tabular}{|c|c|c|c|c|c|c|c|c|c|c|c|c|c|}
\hline \multirow[t]{2}{*}{$\mathrm{n}=727$ (Households) } & \multicolumn{2}{|c|}{ Strongly Satisfied } & \multicolumn{2}{|c|}{ Satisfied } & \multicolumn{2}{|c|}{ Dissatisfied } & \multicolumn{2}{|c|}{$\begin{array}{c}\text { Strongly } \\
\text { Dissatisfied }\end{array}$} & \multicolumn{2}{|c|}{ No View } & \multirow{2}{*}{$\begin{array}{c}\text { Missing } \\
\text { Value } \\
\text { Frq. }\end{array}$} & \multirow[t]{2}{*}{ Mean } & \multirow{2}{*}{$\begin{array}{c}\text { Std. } \\
\text { Deviation }\end{array}$} \\
\hline & Frq. & $\%$ & Frq. & $\%$ & Frq. & $\%$ & Frq. & $\%$ & Frq. & $\%$ & & & \\
\hline Provision of fast and efficient service & 191 & 26.3 & 317 & 43.6 & 52 & 7.2 & 23 & 3.2 & 133 & 18.3 & 11 & 3.84 & 1.00 \\
\hline Availibility of loans with favourable terms & 143 & 19.7 & 197 & 27.1 & 78 & 10.7 & 71 & 9.8 & 136 & 18.7 & 102 & 3.42 & 1.28 \\
\hline A wide range of services offered & 153 & 21.0 & 138 & 43.7 & 55 & 7.6 & 28 & 3.9 & 149 & 20.5 & 24 & 3.73 & 1.02 \\
\hline PB's reputation and image & 199 & 27.4 & 305 & 42.0 & 50 & 6.9 & 28 & 3.9 & 126 & 17.3 & 19 & 3.84 & 1.04 \\
\hline Recommendations by friends\&families & 115 & 15.8 & 202 & 27.8 & 150 & 20.6 & 104 & 14.3 & 126 & 17.3 & 30 & 3.11 & 1.32 \\
\hline Confidentiality of PB & 180 & 24.8 & 279 & 38.4 & 48 & 6.6 & 36 & 5.0 & 111 & 15.3 & 73 & 3.79 & 1.09 \\
\hline Financial counseling provided by employees & 277 & 38.1 & 315 & 43.3 & 23 & 3.2 & 17 & 2.3 & 92 & 12.7 & 3 & 4.12 & 0.91 \\
\hline Informing customer about products\&services & 227 & 31.2 & 292 & 40.2 & 46 & 6.3 & 32 & 4.4 & 114 & 15.7 & 16 & 3.89 & 1.07 \\
\hline Availability of products\&services offered by banks & 165 & 22.7 & 343 & 47.2 & 43 & 5.9 & 28 & 3.9 & 132 & 18.2 & 16 & 3.81 & 0.99 \\
\hline Lower service charges & 187 & 25.7 & 245 & 33.7 & 72 & 9.9 & 60 & 8.3 & 110 & 15.1 & 53 & 3.63 & 1.24 \\
\hline FC transactions with favourable terms & 116 & 16.0 & 164 & 22.6 & 81 & 11.1 & 57 & 7.8 & 149 & 20.5 & 160 & 3.35 & 1.24 \\
\hline Resistance to financial crises & 147 & 20.2 & 251 & 34.5 & 61 & 8.4 & 54 & 7.4 & 140 & 19.3 & 73 & 3.58 & 1.18 \\
\hline \multirow[t]{2}{*}{$\mathrm{n}=109$ (Corporate) } & \multicolumn{2}{|c|}{ Strongly Satisfied } & \multicolumn{2}{|c|}{ Satisfied } & \multicolumn{2}{|c|}{ Dissatisfied } & \multicolumn{2}{|c|}{$\begin{array}{c}\text { Strongly } \\
\text { Dissatisfied }\end{array}$} & \multicolumn{2}{|c|}{ No View } & $\begin{array}{l}\text { Missing } \\
\text { Value }\end{array}$ & Mean & $\begin{array}{c}\text { Std. } \\
\text { Deviation }\end{array}$ \\
\hline & Frq. & $\%$ & Frq. & $\%$ & Frq. & $\%$ & Frq. & $\%$ & Frq. & $\%$ & Frq. & & \\
\hline Provision of fast and efficient service & 30 & 27.5 & 43 & 39.4 & 9 & 8.3 & 8 & 7.3 & 17 & 15.6 & 2 & 3.73 & 1.18 \\
\hline Availibility of loans with favourable terms & 23 & 21.1 & 30 & 27.5 & 12 & 11 & 12 & 11.0 & 23 & 21.1 & 9 & 3.40 & 1.30 \\
\hline A wide range of services offered & 14 & 12.8 & 28 & 25.7 & 10 & 9.2 & 11 & 10.1 & 38 & 34.9 & 8 & 3.24 & 1.15 \\
\hline PB's reputation and image & 25 & 22.9 & 38 & 34.9 & 5 & 4.6 & 9 & 8.3 & 23 & 21.1 & 9 & 3.65 & 1.18 \\
\hline Recommendations by friends\&families & 26 & 23.9 & 31 & 28.4 & 11 & 10.1 & 11 & 10.1 & 22 & 20.2 & 8 & 3.50 & 1.29 \\
\hline Confidentiality of PB & 26 & 23.9 & 36 & 33.0 & 4 & 3.7 & 11 & 10.1 & 27 & 24.8 & 5 & 3.74 & 1.06 \\
\hline Financial counseling provided by employees & 30 & 27.5 & 59 & 54.1 & 1 & 0.9 & 7 & 6.4 & 10 & 9.2 & 2 & 3.97 & 1.00 \\
\hline Informing customer about products\&services & 31 & 28.4 & 33 & 30.3 & 7 & 6.4 & 13 & 11.9 & 22 & 20.2 & 3 & 3.58 & 1.31 \\
\hline Availability of products\&services offered by banks & 26 & 23.9 & 30 & 27.5 & 14 & 12.8 & 10 & 9.2 & 27 & 24.8 & 2 & 3.45 & 1.25 \\
\hline Lower service charges & 28 & 25.7 & 34 & 31.2 & 8 & 7.3 & 14 & 12.8 & 24 & 22.0 & 1 & 3.50 & 1.31 \\
\hline FC transactions with favourable terms & 15 & 13.8 & 21 & 19.3 & 9 & 8.3 & 14 & 12.8 & 28 & 25.7 & 22 & 3.16 & 1.29 \\
\hline Resistance to financial crises & 26 & 23.9 & 36 & 33.0 & 4 & 3.7 & 11 & 10.1 & 27 & 24.8 & 5 & 3.60 & 1.21 \\
\hline
\end{tabular}

\section{Determinants of Respondents' Bank Patronage and Socio- Demographic Factors}

To ascertain whether or not the average perception regarding the variables such as; gender, age, practising religion, education, type of employers, type of business, years of business, monthly income, types of company, number of employees, financial turnover of company are identical for all participants in the 
sample data set, the customers with diverse socio-demographic backgrounds were involved in the survey. To achieve this, $x^{2}$ was computed, and the results of the relationship between bank patronage factors and socio-demographic attributes of household and corporate respondents are reported in Table VII.

Based on the results of analysis and the data as is seen in Table VII that there are differences in bank selection criteria according to gender, age, practising religion, education, type of employers, type of business, years of business and monthly income of households. Practising religion has been idenified as a critical factor that dominates the choice of a PB by household customers.

The criterion like location near my home/place of work was considered as more important by male respondents than the female ones. Furthermore, the criteria of resistance to financial crisis, FC transactions with favourable terms, and location near my home/place of work played a more important role for the household respondents for the age group of 25-34 years. It reveals that the household respondents with a degree of high school considered $P B^{\prime}$ 's reputatation and image and lower service charges more important than those who only had university degree. The households' respondent with an average monthly income range of TL2000-3999 gave more importance to closest behaviour of employees. The respondents working in trade/service sector exhibited more tendencies to opt for interest free banking based on religious motives, as well as business motives such as religious reasons solely and interest-free financial institution. Moreover, the respondents who work on private and self-employed basis gave more weight to resistance to financial crises, PBs reputation and image, closest behaviour of employees and fast and efficient servives. The household respondents running a business less than 5 years expressed that guaranteed deposits in the form of Assurance Fund was the main driver dealing with a PB. In addition to that the result of ki-square between age group and FC transactions with favourable terms appear to be statistically significant. This may lead to the conclution that there is difference between relatively young customers and older ones in terms of dealing with a PB for the criteria of $F C$ transactions with favourable terms. 
In comparison with the $x^{2}$ results for household respondents, the results for corporate respondents do not confim that there are as many differences as between the variables. It appears from the figures in Table VI that the factors of type of company and financial turnover of company were the ones that the most differences observed. Especially, the most striking differences observed were in the attributes and factors between type of company/financial turnover of company and the availability of assurance fund ve resistance to financial crisis. In addition to that the result of ki-square between age of company and FC transactions with favourable terms appear to be statistically significant. Therefore, it is not wroung pronounce that there is a relationship between the age of the company and the criteria of FC transactions with favourable terms.

Not to wrong to pronounce that the corporates which prefer banking in a PB in Turkey tend to act primarly in accordance with the business motives in the process of bank patronage.

\section{Respondents' Satisfaction and Socio- Demographic Factors}

The results from Table VII shows the respondents expressed a certain degree of satisfaction with most aspects of the products/ services provided by PBs. In upper part of Tablo VII illustrates the results of $x^{2}$ for household respondents. The factor of "practising religion" showed the most significant statistical results among the others. All the attributes, except for those of "recommendations by friends/families" and "confidentiality of PB" and socio-demographic factors illustrated differences. The determinant attributes of avalibility of loans with favourable terms, reputation and image, and confidentiality of $P B$ presented statistical significant results, referring to the presence of differences in socio-demographic factors studied in relation to the given satisfaction attributes.

With regard to the findings of the relationship between satisfaction attributes and socio-demographic factors for corporate respondents, it is clear that the factors of type of company and age of company differ for the satisfaction attributes. 


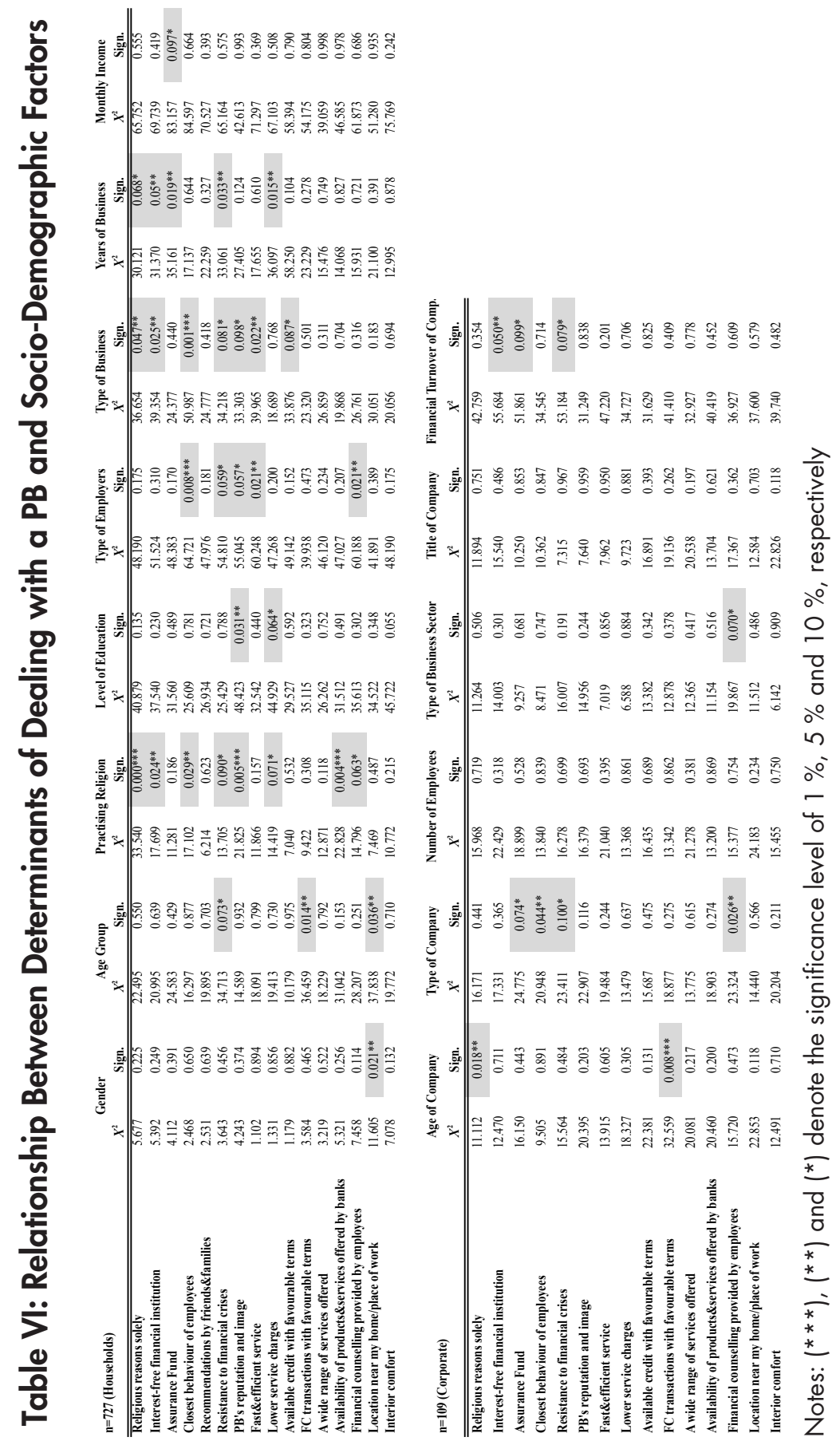




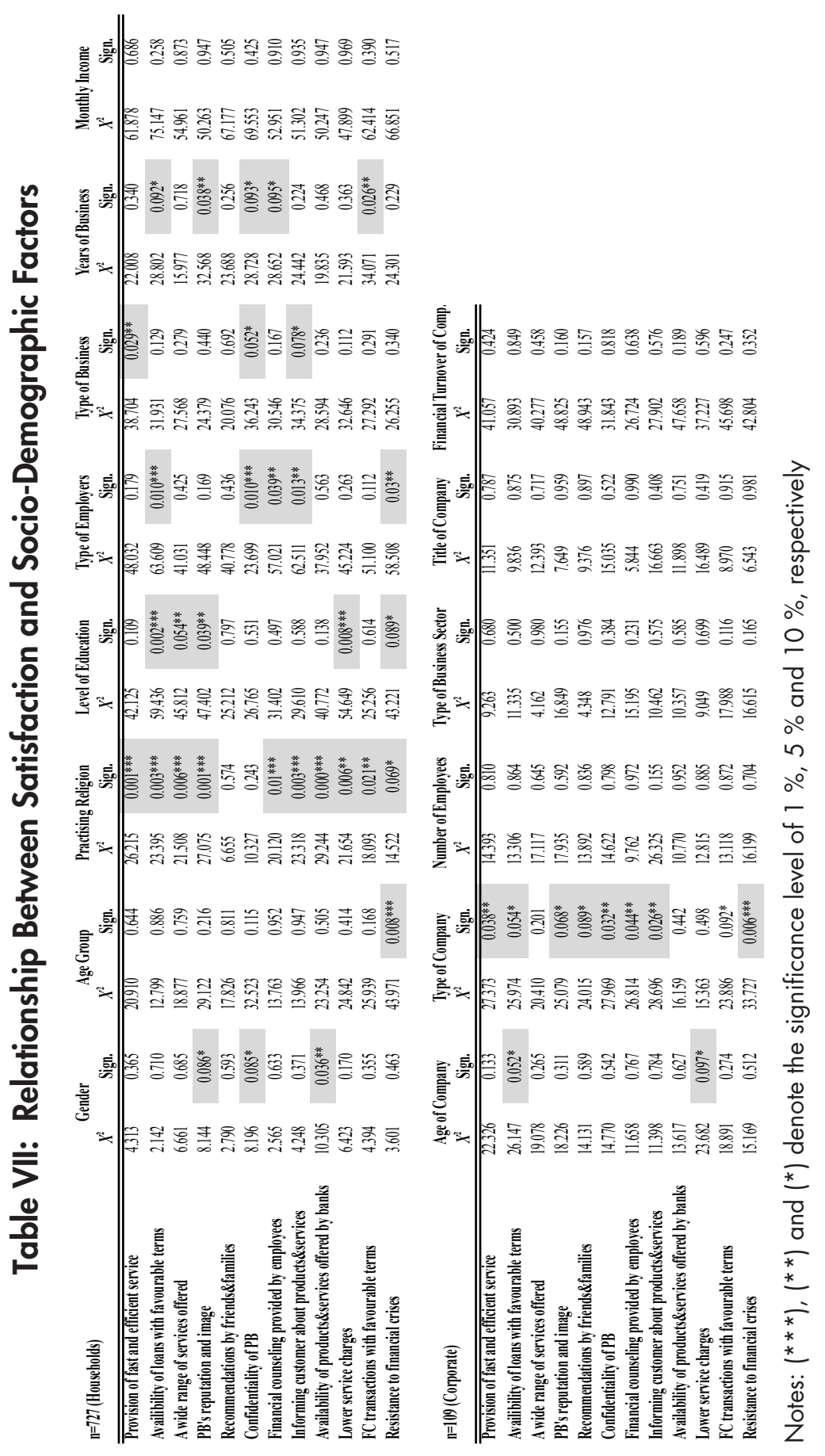




\section{Conclusions and Implications}

The study is designed to explore the use and awareness of household and corporate customers of participation banking and customer satisfaction with the practices of PBs in Turkey. Based on data analysed, our study shows that most of household customers are highly educated. Secondly, the trend of them in the sense of age, majority of the household customers are in the age of 25 to 44 years and one-third of them are of middle incomelevel, engaging in service sector. With regard to corporate customers, most of them engage in trade sector for more than 10 years, owning a business at micro scale.

Our study refers that only one third of the customers have been dealing with a PB for more than 3 years whereas half of the cusomers bank in a PB for a year. This might imply the fact that customer loyalty towards PBs is low since PBs are lacking many pf the feature and requirement that their customers demand. In addition, both household and corporate customers tend to use creditlike participation banking products rather than deposit-like ones. The findings of the study present that the level customer awareness towards participation banking principles is good in general such as Riba. But most of the customers are unaware of Murabahah, Mudarabah and Musharakah principles. The awareness of the availibility of Assurance Fund appears to be higher among corporate customers than household ones.

Regarding the bank patronage factors, both household and corporate customers have chosen to bank with a PB due to staff friendlinessat branches, but there are some other factors that motivate customers for the adoption of participatin banking such as interest-free financial institution, efficient service, and financial counselling offered by staff. On the contrary to the findings of earlier studies by Okumus (2015) and Okumus \& Guneren Genc (2013), the factor of religious reasons only has not been the one of main drivers behind dealing with a PB for both type of customers anymore. Based on analysis, the results of our study implies that PBs' customers have acted in a more rational manner in their financial 
desicions in comparison with those participated in the similar surveys in the early and mid-2000s.

Moreover, the results suggest that over all PBs' customers are mostly satisfied with participation banking products offered and efficiency in transactions. However, the level of satisfaction with the attribute of financial counselling provided by staff to corporate customers appeared to be low.

With regard to determinants of bank patronage and sociodemographic factors, our study concludes that practising religion is one of the main factor for the household customers in their bank selection process as well as availability of Assurance Fund. Above all, such as; type of company and financial turnover of company present a relationship with bank patronage factors such as availability of Assurance Fund and resistance to financial crisis. Therefore, it is not wrong to pronounce that corporate customers of the PBs in Turkey tend to act primarily in accordance with business motives in their bank selection. The degree of satisfaction with $\mathrm{PBs}^{\prime}$ products/services is determined by the attributes of loans with favourable terms, reputation and image, and confidentiality of PB to a certain level whereas type of company and age of company are the attributes for corporate customers.

The researchers feel that in order for the full-fledged PBs to gain more market share, not only the participation banking products/services but also the fundementals of participation banking should be internalised by customers, staff and other parties related, leading to the awareness of the original paradigm of Islamic banking and finance. Secondly, the PBs are obliged to offer products/services that meet the SMEs' financial needs rather than restricting themselves to the needs of micro businesses in Turkey. As a result, they can gain a growing customer base of the Turkish people, especially those who have been kept a distance from the historically set perception of Islamic banking in Turkey. Lastly, the PBs need to prove that they are commercially viable as the other counterparts in the financial markets. 


\section{REFERENCES}

Abdi, M.H. 2015. Factors Influencing Islamic Banking Selection Criteria Among International Students of Selected Universities in Northern States of Malaysia. Master in Islamic Finance Banking University Utara Malaysia. Unpublished Master Thesis.

Abdullah, A. A., Sidek, R., and A. A. Adnan. 2012. Perception of Non-Muslims Customers towards Islamic Banks in Malaysia. International Journal of Business and Social Science. 3(1 1): 151-163.

Al-Ajmi, J., H. A. Hussein and N. Al-Saleh. 2009. Clients of Conventional and Islamic Banks in Bahrain: How They Choose Which Bank to Patronize. International Journal of Social Economics. 36(11): 1086-1112.

Amin, M., Z. Isa and R. Fontaine. 2013. The Role of Customer Satisfaction in Enhancing Customer Loyalty in Malaysian Islamic Banks. The Service Industries Journal. 31 (9): 1519-1532.

Amin, H. 2008. Choice criteria for Islamic Home Financing: Empirical Investigation Among Malaysian Bank Customers. International Journal of Housing Markets and Analysis. 1(3): 256-274.

Artar, O., H. S. Okumus and E. Guneren Genc. 2016. Assessing Customer Awareness and Selection Criteria of Islamic and Conventional Banks in Turkey. Doğuș Üniversitesi Dergisi. 17(2): 255-271.

Asutay M., Ergec. 2013. Developments in Islamic Banking in Turkey: Emergen$\mathrm{ce}$, Regulation and Performance. In Islamic Finance in Europe: Towards a Plural Financial System. Cattelan, V. Cheltenham: Edward Elgar Publishing.

Bilir, A., H. Özgen 2010. Katılım Bankalarında Müsteri Memnuniyetinin Belirlenmesi Üzerine Hatay ilinde Bir Araștırma. C..Ü. The Journal of Social Sciences Institute. 19(3): 39-42.

Boulam, H. 2015. Participation Banking in Turkey: Comparative analysis, Z/ Yen Reference \& Perspectives. Universita> Degli Studi Di Torino School of Management and Economics Master's Degree in International Accounting. Unpublished Master.

Dhurup, M., J. Surujlal and E. Redda 2014. Customer Perceptions of Online Banking Service Quality and its Relationship with Customer Satisfaction and Loyalty. Mediterranean Journal of Social Sciences. 5 (8): 72-80.

Ergec, E. H., B.G. Kaytancı and M. Toprak. 2014. Katılım Bankası Müșterilerinin Bankacılık Sistemi Kullanım Tercihleri: Mevduat Bankaları için İslami Bankacılık Penceresi. Tüketici ve Tüketim Araștırmaları Dergisi. 6 (2): 53-90.

Gaith, A. and A. Worthington. 2009. Libyan Business Firm Attitudes towards Islamic Methods in Finance", Griffitts Business School Discussion Papers Finance. Available at SSRN 1370752. 
Haron, S., N. Ahmad and S. L. Planisek. 1994. Bank Patronage Factors of Muslim and Non-Muslim Customers", International Journal of Bank Marketing. 12(1): 32-40.

Kader, R. A., R. H. Zakaria, N. Razali and N. Abdullah. 2014. Why this Bank? Understanding Customers' Preference for an Islamic Bank in a Competitive Market. Journal of Islamic Economics, Banking and Finance. 10 (2):138-153.

Kashif M., M. A. Rehman and L. Pileliene. 2016. Customer Perceived Service Quality and Loyalty in Islamic Banks: A Collectivist Cultural Perspective. The TQM Journal. 28(1): 62-78.

Kaytancı, A., E..H. Ergeç and M. Toprak. 2013. Katılım Bankası Müșterilerinde Bankacılık Ürün ve HizmetlerineYönelik Memnuniyet: Türkiye Örneği. International Conference on Eurasian Economies: 801-811.

Lee, K., S. Ullah. 2011 . Customers> Attitude Toward Islamic Banking in Pakistan. International Journal of Islamic and Middle Eastern Finance and Management. 4(2): 131- 145 .

Okumus, H.S. 2005. Interest Free Banking in Turkey: A Study of Customer Satisfaction and Bank Selection Criteria. Journal of Economic Cooperation. 26(4): 51-86.

Okumus, H.S. and Guneren Genc, E. 2013. Interest free banking in Turkey: A Study of Customer Satisfaction and Bank Selection. The European Scientific Journal. 9(16): 144-166.

Ozsoy, I., B. Görmez and S. Mekik. 2013. Türkiye'de Katılım Bankalarının Tercih Edilme Sebepleri: Ampirik bir Tetkik. Celal Bayar Üniversitesi Yönetim ve Ekonomi Dergisi. 20 (1): 187-206.

Saad, N. M. 2012. Comparative Analysis of Customer Satisfaction on Islamic and Conventional Banks in Malaysia. Asian Social Science. 8(1): 73-80.

Savașan, F., M. Saraç and T. Gürdal. 2013. Exploring the Demand Side Issues in Particapition Banking in Turkey: Questionnaire Survey on Current Issues and Proposed Solutions. Afro Eurosian Studies. 2(1-2): 111-125.

Sayani, H. 2015. Customer satisfaction and loyalty in the United Arab Emirates Banking Industry. International Journal of Bank Marketing. 33 (3): 351-375.

Sendoğdu, A. 2014. A Survey on the Customer Satisfaction and Customer Loyalty at the Private, State and Participation Banks. Suleyman Demirel University The Journal of Faculty of Economics and Administrative Sciences. 19 (1): 91-106.

The Banker Global Finance Intellegence. http://www.thebanker.com/Top1000/The-Banker-Top-1000-World-Banks-2015-ranking-WORLD-PressIMMEDIATE-RELEASE

Youssef, M. M. H., W. Kortam, E. Abou-Aish and N. El-Bassiouny. 2015. Effects of Religiosity on Consumer Attitudes toward Islamic Banking in Egypt. International Journal of Bank Marketing. 33 (6): 786-807. 